\title{
MIND MAPPING: A METACOGNITIVE APPROACH TO ELEVATE ACHIEVEMENT IN MATHEMATICS OF SECONDARY SCHOOL STU- DENTS
}

\author{
Anupam Sain ${ }^{1}$ and Dr. Kusum ${ }^{2}$ a \\ ${ }^{1}$ Research Scholar, Department of Education, Panjab University, Chandigarh, India. Tel.: 9888831724 \\ ${ }^{2}$ Associate Professor, Government, College of Education, sector 20-D, Chandigarh, India. Tel.: 9878104782
}

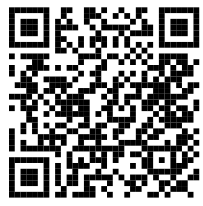

Associate Professor, Government, College of Education, sector 20-D, Chandigarh, India. Tel.: 9878104782

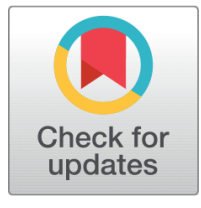

Received 6 July 2021

Accepted 17 July 2021

Published 31 July 2021

Corresponding Author

Anupam Sain, anu.sn23@gmail.co $\mathrm{m}$

DOI 10.29121/

granthaalayah.v9.i7.2021.4115

Funding: This research received no specific grant from any funding agency in the public, commercial, or not-for-profit sectors.

Copyright: (C) 2021 The Author(s). This is an open access article distributed under the terms of the Creative Commons Attribution License, which permits unrestricted use, distribution, and reproduction in any medium, provided the original author and source are credited.

\section{ABSTRACT}

Metacognitive Strategies have always played a vital role in teaching learning process. Mathematical learning is solely based on these strategies. Several metacognitive approaches have been adopted by teachers to elevate the learning levels of students in mathematics. The basic feature of mathematics learning is to enable human mind to think logically. Mind mapping provides the students enough space to think about his thinking while learning mathematics. In this study the investigator aims find the answer for the question that how the learning levels of students can be augmented using Mind mapping as a metacognitive approach? For this an Experiment was conducted on secondary school students of Sangrur district in Punjab. This paper provides a brief overview of the study.

Keywords: Mind Mapping, Metacognitive Strategies, Mathematics Achievement

\section{INTRODUCTION}

In Mathematics Learning metacognitive strategies have played an indispensable role. A metacognitive approach in mathematics correlates with fundamental components of metacognition that are applicable to student for mathematics learning. There are numerous mechanisms affect the learning of mathematical concepts and processes, comprising cognitive development, neurological development, syntax, and perceptive. Self-monitoring and self-control over thinking are two most important components in metacognitive strategies. Mind Maps were originated by Tony Buzzan. Mind mapping is a technique of connecting main ideas using pictures, lines and links. A principal idea is connected through lines to other ideas which in turn are connected with other allied ideas. A mind map construction needs self-monitoring and selfcontrol over thinking process which brings mathematics in metacognitive strategies. 


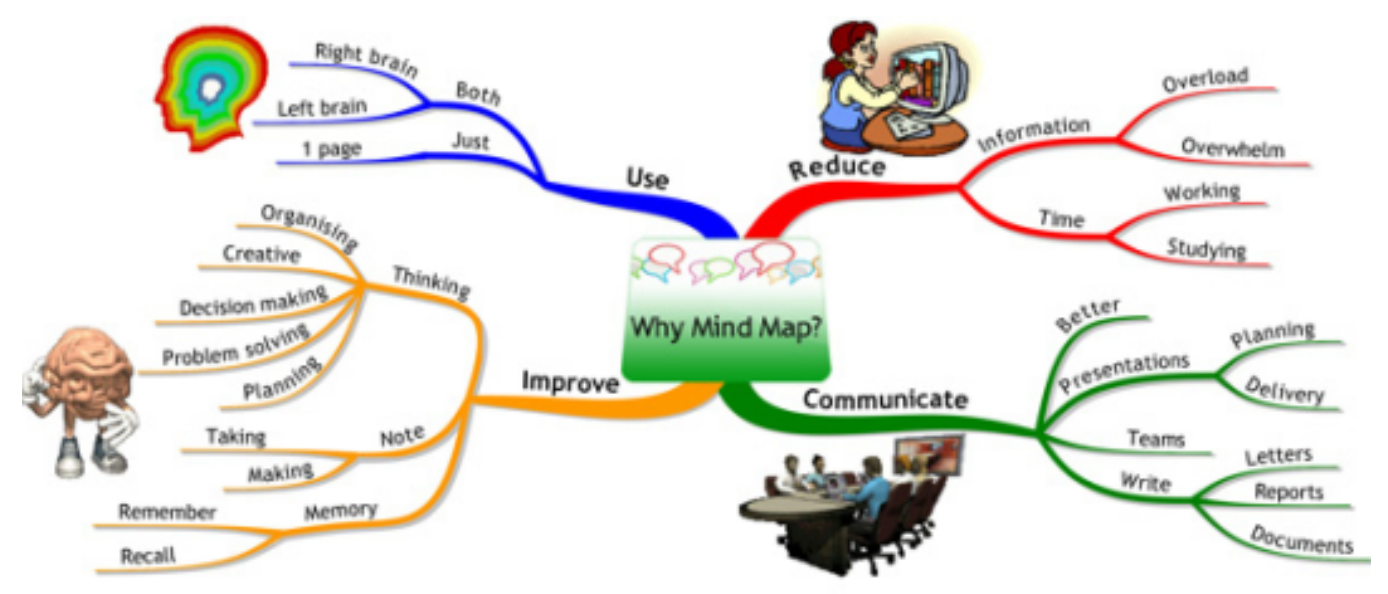

Figure 1 Importance of Mind Maps in Learning http://www.mind-mapping.co.uk/mind-map-exa mples/

\section{SIGNIFICANCE OF STUDY}

Since decades mathematics learning have been linked with traditional learning techniques. Those traditional techniques have made mathematics a rigid subject where students feel themselves abide by the rules. Students some time got bored with them and lose interest in the subject. Mind mapping provides the students a chance to express their own ideas and demonstrate their creative skills along bounded with mathematics principals. Mind maps helps students in development of cognitive abilities using their metacognition processes. This study was conducted to enquire the relationship between mathematics achievement and Mind Mapping.

\section{OBJECTIVES OF THE STUDY}

- To develop a Mind Mapping programme in Mathematics

- To study the mathematics achievement of students.

- To study the effect of Mind mapping on Mathematics Achievement.

- To compare the effect of Mind Mapping and Traditional teaching method on annual scores in mathematics of secondary school students.

\section{HYPOTHESIS OF THE STUDY}

- There will be no significant effect of Mind Mapping on mathematics achievement of secondary school students.

- There will be no significant effect of Mind Mapping and Traditional teaching method on male and female secondary school students.

- There will be no significant effect of Mind Mapping on annual scores in mathematics of secondary school students. 


\section{DESIGN OF THE STUDY}

The study was based on experimental research. Pre-test - post-test two group design was

adopted for the study. The experimental group was exposed to mind mapping, whereas control group was exposed to traditional teaching strategy.

\section{RESEARCH TOOLS}

- Mind Mapping Programme

- Mathematics Achievement Test

- Achievement in mathematics of students in final term Examination

\section{SAMPLE OF THE STUDY}

This study was conducted in Sangrur district of Punjab. The population for the study was all the $9^{\text {th }}$ grade students of Sangrur district. Purposive Sampling Technique was used for in the study. The study was conducted on random sample of 100 Secondary school students of class IX from Govt. Schools of Punjab.

\section{PROCEDURE}

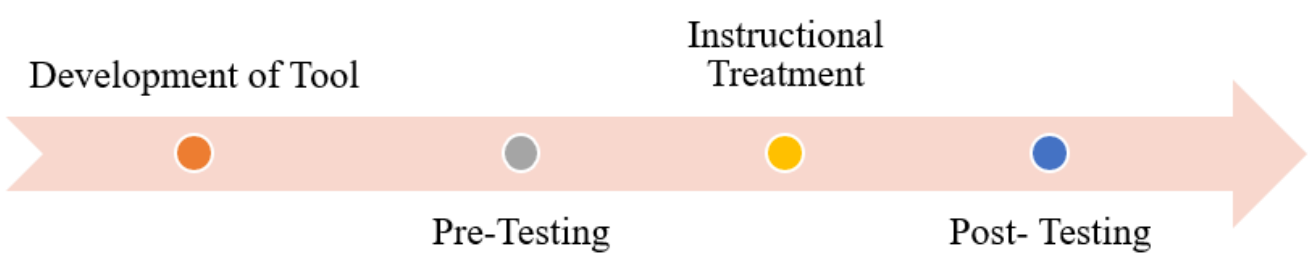

\section{HYPOTHESES TESTING}

\section{Hypothesis-1}

There will be no significant effect of Mind Mapping on mathematics achievement of secondary school students.

The researcher explored the of difference between post test scores and annual term mathematics achievement scores with two factor analyses of variance for repeated measurements on a single factor using ANOVA test. The analysis of scores showed a significant difference in achievement scores in mathematics. These results rejected the null hypothesis. 
Table 1 Comparison based on Experimental and Control groups' results of pre-test and posttest-scores in mathematics

\begin{tabular}{|c|c|c|c|c|c|c|}
\hline Source of Variance & $\begin{array}{l}\text { Sum of } \\
\text { squares }\end{array}$ & df & $\begin{array}{l}\text { Mean } \\
\text { Sq. }\end{array}$ & $\mathbf{F}$ & $\mathbf{P}$ & $\begin{array}{l}\text { Signifi- } \\
\text { cance }\end{array}$ \\
\hline $\begin{array}{l}\text { Between groups Experimental and } \\
\text { Control groups }\end{array}$ & 1890.39 & 1 & 1890.39 & 8.35 & .007 & .152 \\
\hline Error & 10649,74 & 99 & 105.645 & & & \\
\hline \multicolumn{7}{|c|}{ In Groups } \\
\hline Measure (pre-test-post-test) & 13867.54 & 1 & 13867.54 & 251.63 & .000 & .795 \\
\hline Group* Measure & 1690.95 & 1 & 1690.95 & 40.33 & .000 & .398 \\
\hline Error & 3484.54 & 99 & 34.18 & & & \\
\hline Total & & 100 & & & & \\
\hline
\end{tabular}

\section{Hypothesis-2}

There will be no significant effect of Mind Mapping and Traditional teaching method on male and female secondary school students.

To explore the effect of gender on achievement scores in mathematics Analysis of Variance test and Scheffe test were applied for data analysis. The test results showed that there was no significance difference on achievement in mathematics in terms of gender. These results accepted the null hypothesis.

\section{Table 2 Comparison ofpost-test scores based on gender}

\begin{tabular}{ccccccc}
\hline Variable Gender & Source of Variance & Sum of squares & df & Mean Sq. & F & P \\
& Between groups & 3846.356 & 3 & $1,182.09$ & 7.98 & .000 \\
& In Groups & 8859.356 & 97 & 91.993 & & \\
& Total & & 100 & 34.18 & & \\
\hline
\end{tabular}

\section{Hypothesis-3}

There will be no significant effect of mind mapping on annual scores in mathematics of secondary school students.

In order to assess significant difference between annual scores in mathematics averages of the experimental group and the control group, the independent sample tests were performed. The analysis showed that there is a significant difference between groups in favour of experimental group The experimental group scored an average of 89.70 while the control group scored an average score of 72.30 .

Table 3 Comparison of Annual Scores of both groups

\begin{tabular}{cccccccc}
\hline \multicolumn{7}{c}{ Leven Test } \\
Groups & $\mathbf{n}$ & $\mathbf{X}$ & SS & $\mathbf{F}$ & $\mathbf{P}$ & $\mathbf{T}$ & $\mathbf{P}$ \\
\hline Experimen & 50 & 89.70 & 12.62 & .01 & .952 & 2.95 & .19 \\
\hline Control & 50 & 72.30 & 11.28 & & & \\
\hline Total & 100 & & & & \\
\hline
\end{tabular}




\section{CONCLUSION}

The study revealed that Mind Mapping provided the students a chance to selfregulate and control their thinking patterns. Mind mapping significantly affected the achievements of students. Following facts were revealed by the experiment.

- Mind Mapping augmented the level of Mathematics Achievement of the students.

- The gender did not dominate the Mathematics Achievement of Experimental group.

- Mind Mapping instigated positive effect on Academic Achievement.

\section{REFERENCES}

Bas, F. (2016). Pre-Service Secondary Mathematics Teachers 'Metacognitive Awareness And Metacognitive Behaviours In Problem Solving Processes. Universal Journal of Educational Research, 4(4), 779-801.

Bransford, J. D., Brown, A. L., \& Cocking, R. R. (2000). How People Learn. Brain, Mind, Experience, And School, National Academia Press, Washington, DC, USA.

Desoete, A., \& Craene, B. D. (2019). Metacognition And Mathematics Education: An Overview. ZDM Mathematics Education., 51, 565-575. Retrieved from Https://Doi.Org/10.1007/ S11858-019-01060-W

Izzati, L. R., \& Mahmudi, A. (2018). The Influence Of Metacognition In Mathematical Problem Solving. Retrieved from Https://Iopscience.Iop.Org/Journal/1742-6596

Schneider, W., \& Artelt, C. (2010). Metacognition And Mathematics Education ZDM - International Journal On Mathematics Education. Retrieved from Http://Dx.Doi.Org/10.1007/ S11858-010-0240-2.

Verschaffel, L., Depaepe, F., \& Mevarech, Z. (2019). Learning Mathematics In Metacognitively Oriented ICT-Based Learning Environments: A Systematic Review Of The Literature. Education Research International, 2019. Retrieved from Https://Doi.Org/10 $.1155 / 2019 / 3402035$. 